\title{
Reasons for cattle retirement on feeding farms
}

\author{
Maksim Zhukov ${ }^{1, *}$, Yurij Alekhin ${ }^{1}$, Ivan Kalyuzhny ${ }^{2}$, Vasiliy Dorozhkin ${ }^{3}$, and Anatoliy Stekolnikov ${ }^{4}$ \\ ${ }^{1}$ All-Russian Veterinary Research Institute of Pathology, Pharmacology, and Therapy, 394087 Voronezh, Russia \\ ${ }^{2}$ Saratov State Agrarian University named after N.I. Vavilov, 410012 Saratov, Russia \\ ${ }^{3}$ All-Russian Research Institute of Veterinary Sanitation, Hygiene and Ecology - branch of Federal Scientific Centre - All-Russian \\ Research Institute of Experimental Veterinary Medicine of the Russian Academy of Research, Moscow, Russia \\ ${ }^{4}$ Saint-Petersburg State Academy of Veterinary Medicine, 196084 St. Petersburg, Russia
}

\begin{abstract}
The study has been carried out at two livestock complexes specializing in the production of beef to investigate the causes of non-productive retirement of animals. The structure of the causes of death or necessary slaughter of young cattle was determined by the results of pathological autopsy $(\mathrm{n}=2816)$. Moreover, it was revealed that in $83.5 \%$ of the animals, morphological changes in the respiratory organs prevailed, which in $40.2 \%$ of the cases were thanatogenetically significant. The pathology of the digestive system was found in $29.6 \%$ of animals, and in $14.9 \%$ of cases they caused death. Pathology of the kidneys and urinary tract most often occurred at the age of 4-6 months and caused the retirement of 7.6-9.4\% of the animals. The role of cardiovascular pathology in the structure of the causes of retirement increases in young animals aged 8-11 months, while that of diseases of the joints and distal extremities rises at the final stage of their fattening. Clinical and expert evaluation of the activity of veterinary specialists $(n=12)$ showed that they correctly identified the underlying disease in $74 \%$, concomitant pathologies in $17.9 \%$, and complications in $5 \%$ of diseased. Therefore, one of the problems of diagnosing diseases in young cattle during the period of growing and fattening is an incomplete diagnosis due to the low detection rate of concomitant pathologies and complications, some of which are of decisive thanatogenetic significance.
\end{abstract}

\section{Introduction}

Cattle breeding is one of the most important sectors of agriculture in Russia, providing the population with unique composition of meat [1]. However, despite the increase in beef production, the country remains in deficit, and in the structure of meat imports it amounts to $55-58 \%$ [2].

One of the factors limiting the development of the meat industry, the effectiveness of public and private investment is animal health, the violation of which is accompanied not only by a decrease in the intensity of growth and product quality, but is also the main cause of their non-productive retirement.

Most studies of the health status of fattening animals are devoted to individual topical nosological units, such as respiratory diseases [3, 4], extremities [5], etc. However, insufficient attention is paid to the analysis of the structure of non-productive animal retirement, although this very indicator allows evaluating the production efficiency and determining ways to increase its profitability [6].

One of the factors that creates the risk of an error in assessing the structure of the causes of death or a serious condition of a diseased is the comprehensiveness of the diagnosis, in particular, determination of the tanogenetic significance of the revealed pathological changes [7].
In this case, the most objective information can be obtained only on the basis of pathological autopsy, which allows specifying the diagnosis, evaluating the usefulness of intravital studies and the choice of therapy, i.e. clinical expert work is carried out, the results of which will improve the effectiveness of treatment and preventive measures.

The aim of this work was to study the structure of the causes of non-technological retirement of cattle in farms specializing in the rearing and fattening of young cattle.

\section{Materials and methods}

Studies on the causes of non-productive livestock retirement were carried out from January 2017 to December 2018 in the Voronezh and Belgorod regions in two livestock complexes specializing in beef production, the average annual number of which is 5.5 and 6.2 thousand calves.

For rearing and fattening, young animals at the age of 2-3 months were purchased in 40 farms-reproducers of 7 regions of the Central Federal District. The production facilities are equipped with a supply and exhaust ventilation system with exhaust through the shafts, and in summer, in addition to a mechanical air supply, the manure is removed by a recirculation-chute version of the hydraulic flush.

* Corresponding author: maxim.zhukoff2015@yandex.ru 
Animals were kept for $16-18$ months in group quarters of 18-20 heads on cast-iron trellised floors. Their diet corresponded to typical feeding norms [8]; watering was carried out from open-type group drinking bowls into which water with a temperature of $+5 \ldots+7{ }^{\circ} \mathrm{C}$ was supplied corresponding to sanitary and hygienic requirements [9].

The causes of the retirement of animals were determined on the basis of the results of postmortem autopsy, which was carried out according to the generally accepted method in compliance with all the rules of public and personal safety [10] in a field laboratory equipped with a section table, a table for instruments, a table for recordings (keeping a protocol), and a container with a cabinet for storage of tools and consumables, a cabinet for workwear, a container for storing disinfectant solutions, an auto-refrigerator for storing pathological material, a container for the collection and primary disinfection of corpses.

To eliminate conflicts of interest during clinical and expert work, which is based on differences in the interpretation of the results of a post-mortem or postslaughter examination, when assessing the causes of animal death, we took into account the severity of pathomorphological changes with the definition of the underlying disease that led to the death or necessary slaughter of the animal $[7,11]$. If there was more than one such disease, the one that was of greater importance in thanatogenesis was chosen [12].

\section{Results and discussion}

On the farms where the studies were conducted, the nonproductive retirement of animals amounted to 2821 animals, of which $5(0.17 \%)$ were abducted, 795 $(28.20 \%)$ died and $2021(71.63 \%)$ were forcedly slaughtered. An analysis of the results of autopsy of 2816 corpses of fallen or carcasses of reluctantly slaughtered showed that $83.5 \%$ of animals had morphological changes in the respiratory system.

In $40.2 \%$ of cases, restrictive processes were observed with a decrease in the elasticity of the lung tissue and a decrease in the functional volume of the lungs due to their petrification, atelectasis and / or edema, massive inflammatory infiltration and / or exudation into the alveoli, which are known to be Tanatogenetically significant [13-15].

In $43.3 \%$ of animals, morphological changes were less pronounced and were considered as background or concomitant pathologies. Most often, respiratory tract lesions were recorded in calves during the first 90 days of their stay in fattening farms, but at the age of seven months, their prevalence decreases by $20.3 \%$, and then after a slight increase at the end of the growing period (10-12 months) decreases during fattening.

The following in terms of relevance are diseases of the digestive system, morphological changes of which were found in $29.6 \%$ of animals.

Moreover, in $14.9 \%$ of cases, it is highly probable that they caused death and appeared in the gastrointestinal tract in the form of diffuse hemorrhagic inflammation of the abomasum and/or intestines, purulent catarrhs, blockage of omasum, and tympany of rumen, prolapse of the rectum with hemorrhagic infarction, and massive dystrophy of the parenchyma with hepatomegaly, a combination of cirrhosis with ascites in the liver and/or spleen hyperplasia.

In $14.7 \%$ of animals, diseases of the digestive system were regarded as the main ones, but death occurred as a result of their complication by other pathologies. Most often, pathological changes in the gastrointestinal tract were diagnosed within two months after the delivery of calves, but then their prevalence decreased, while the frequency of damage to the hepatobiliary system increased at the end of fattening.

Morphological changes in the kidneys were detected in $7.4 \%$ of dead and reluctantly killed animals, while the highest frequency was observed at the age of 4-6 months. Moreover, only in $1.5 \%$ of cases of autopsy, diseases of the urinary system were of tanatogenetic significance and manifested as necrotic nephrosis, pyeloor urinogenic purulent nephritis in combination with ascites.

The prevalence of lesions of the cardiovascular system was $4.8 \%$, and that for the peritoneum was $4.3 \%$, but the peak of these pathologies was noted at the age of $8-11$ and 4-8 months, respectively. Moreover, myocarditis, pericarditis, right ventricular hypertrophy and ascites, which are known [16] to be a common cause of death, were most often noted.

Surgical diseases occurred in $4.8 \%$ of the examined animals mainly in the form of severe injuries, complications after a caudotomy or bloody dehorning, acting in most cases as the cause of the necessary slaughter of animals. Injuries were diagnosed on average in $4.4 \%$ of the examined animals, and their prevalence was characterized by a 2.5 -fold increase in age from 4 to 10 months with the subsequent preservation of the achieved level (5.6-6.1 \%) by the end of fattening, although at the age of 12,13 and 15 months the risk of injury increased.

The incidence of pathologies of the distal extremities and joints on average was 2.6 and $3 \%$, respectively. These diseases did not have a tanatogenetic significance, but were among the main causes of necessary slaughter of animals. The dynamics of the morbidity is characterized by an increase in cases of arthritis and arthrosis in young cattle aged 9 months and older, and increase of diseases of the distal limb at the final stage of feeding.

In veterinary medicine there is no approved algorithm for conducting a clinical expert assessment of the activity of veterinary specialists. Therefore, we used the experience of humanitarian medicine.

Comparing the clinical (intravital) diagnosis made by veterinarians $(\mathrm{n}=12)$ working at the examined enterprises and the results of pathological autopsy (postmortem diagnosis) conducted by specialists of the AllRussian Research Veterinary Institute of Pathology, Pharmacology and Therapy, it was found that the main disease was revealed correctly in $74 \%$ of cases, concomitant pathologies in $17.9 \%$, and complications in $5 \%$ of diseased. ICD-10 determines that iatrogenic fatal 
complications are indicated as the initial cause of death in case of erroneous overdose, improper prescription of the drug, unprofessionally (with errors, not according to indications, but with underestimation of the patient's characteristics) performed diagnostic or therapeutic measure.

Other iatrogenic, even fatal, complications that occurred when treatment was delivered correctly and according to the indications should be considered as complications of the underlying disease [17].

Therefore, it can be stated that in the case of $26 \%$ of calves a medical error was present, which became the initial cause of death, because the main disease was not detected and there was an erroneous appointment of treatment.

In $95 \%$ of cases of death or necessary slaughter, complications of the main disease were not noticed, which is not a medical error, but indicates the inferiority of diagnostic procedures. During the clinical examination, in $83 \%$ of the animals the presence of concomitant pathologies was not detected that were identified during autopsy. In this case, there is a controversial situation in assessing the actions of veterinarians.

When prescribing a course of therapy that involves reducing the risk of developing concomitant pathologies, these iatrogenic complications are assessed as complications of the underlying disease, but not a medical error.

However, there is also an unprofessional implementation of diagnostic measures, in particular, "underestimation of the patient's characteristics", which gives reason to state a medical error that caused death or necessary slaughter.

Table 1. Localization of the main pathological changes identified during autopsy of fallen and necessarily slaughtered calves

\begin{tabular}{|c|c|c|c|c|c|c|c|c|c|c|c|c|c|c|c|c|}
\hline \multirow{2}{*}{$\begin{array}{l}\text { Location of } \\
\text { major } \\
\text { pathological } \\
\text { changes }\end{array}$} & \multicolumn{16}{|c|}{ Age [month] } \\
\hline & 3 & 4 & 5 & 6 & 7 & 8 & 9 & 10 & 11 & 12 & 13 & 14 & 15 & 16 & 17 & 18 \\
\hline $\begin{array}{l}\text { cardiovascular } \\
\text { system } \\
\text { [animals] }(\%) \\
\end{array}$ & $\begin{array}{c}8 \\
(2.2)\end{array}$ & $\begin{array}{c}12 \\
(3.75)\end{array}$ & $\begin{array}{c}12 \\
(4.0)\end{array}$ & $\begin{array}{c}12 \\
(3.8)\end{array}$ & $\begin{array}{c}12 \\
(5.7)\end{array}$ & $\begin{array}{c}11 \\
(7.4)\end{array}$ & $\begin{array}{c}11 \\
(7.3)\end{array}$ & $\begin{array}{c}12 \\
(7.4)\end{array}$ & $\begin{array}{c}9 \\
(6.92)\end{array}$ & $\begin{array}{c}7 \\
(6.2)\end{array}$ & $\begin{array}{c}7 \\
(6.2)\end{array}$ & $\begin{array}{c}6 \\
(5.9)\end{array}$ & $\begin{array}{c}3 \\
(4.3)\end{array}$ & $\begin{array}{c}4 \\
(3.9)\end{array}$ & $\begin{array}{c}4 \\
(4.0)\end{array}$ & $\begin{array}{c}5 \\
(5.1)\end{array}$ \\
\hline $\begin{array}{l}\text { respiratory } \\
\text { organs } \\
\text { [animals] }(\%)\end{array}$ & $\begin{array}{c}154 \\
(41.8)\end{array}$ & $\begin{array}{c}140 \\
(43.75)\end{array}$ & $\begin{array}{c}136 \\
(45.3)\end{array}$ & $\begin{array}{c}140 \\
(44.8)\end{array}$ & $\begin{array}{c}74 \\
(35.7)\end{array}$ & $\begin{array}{c}60 \\
(38.9)\end{array}$ & $\begin{array}{c}59 \\
(39.4) \\
\end{array}$ & $\begin{array}{c}65 \\
(40.12)\end{array}$ & $\begin{array}{c}54 \\
(41.54)\end{array}$ & $\begin{array}{c}45 \\
(38.9)\end{array}$ & $\begin{array}{c}42 \\
(37.6)\end{array}$ & $\begin{array}{c}40 \\
(36.9)\end{array}$ & $\begin{array}{c}28 \\
(34.7) \\
\end{array}$ & $\begin{array}{c}32 \\
(33.8)\end{array}$ & $\begin{array}{c}34 \\
(32.6)\end{array}$ & $\begin{array}{c}30 \\
(31.6)\end{array}$ \\
\hline $\begin{array}{l}\text { gastrointestina } \\
1 \text { tract } \\
\text { [animals] }(\%)\end{array}$ & $\begin{array}{c}94 \\
(25.6)\end{array}$ & $\begin{array}{c}64 \\
(20.0)\end{array}$ & $\begin{array}{c}46 \\
(15.3)\end{array}$ & $\begin{array}{c}44 \\
(14.1)\end{array}$ & $\begin{array}{c}36 \\
(17.3)\end{array}$ & $\begin{array}{c}22 \\
(14.3)\end{array}$ & $\begin{array}{c}22 \\
(14.6)\end{array}$ & $\begin{array}{c}19 \\
(11.73)\end{array}$ & $\begin{array}{c}16 \\
(12.3)\end{array}$ & $\begin{array}{c}14 \\
(12.0)\end{array}$ & $\begin{array}{c}12 \\
(10.7)\end{array}$ & $\begin{array}{c}12 \\
(11.1)\end{array}$ & $\begin{array}{c}10 \\
(12.5)\end{array}$ & $\begin{array}{c}12 \\
(12.5)\end{array}$ & $\begin{array}{c}14 \\
(13.4)\end{array}$ & $\begin{array}{c}12 \\
(12.5)\end{array}$ \\
\hline $\begin{array}{l}\text { liver and } \\
\text { biliary tract } \\
\text { [animals] }(\%)\end{array}$ & $\begin{array}{c}53 \\
(14.3)\end{array}$ & $\begin{array}{c}32 \\
(10.0)\end{array}$ & $\begin{array}{c}30 \\
(10.0)\end{array}$ & $\begin{array}{c}33 \\
(10.5)\end{array}$ & $\begin{array}{c}32 \\
(15.5)\end{array}$ & $\begin{array}{c}22 \\
(14.2)\end{array}$ & $\begin{array}{c}21 \\
(14.3)\end{array}$ & $\begin{array}{c}26 \\
(16.05)\end{array}$ & $\begin{array}{c}20 \\
(15.38)\end{array}$ & $\begin{array}{c}18 \\
(15.5)\end{array}$ & $\begin{array}{c}18 \\
(16.1)\end{array}$ & $\begin{array}{c}18 \\
(16.6)\end{array}$ & $\begin{array}{c}14 \\
(17.5)\end{array}$ & $\begin{array}{c}16 \\
(16.6)\end{array}$ & $\begin{array}{c}16 \\
(15.3)\end{array}$ & $\begin{array}{c}16 \\
(16.6)\end{array}$ \\
\hline $\begin{array}{l}\text { kidneys and } \\
\text { urinary tract } \\
\text { [animals] }(\%)\end{array}$ & $\begin{array}{c}27 \\
(7.3)\end{array}$ & $\begin{array}{c}28 \\
(8.75)\end{array}$ & $\begin{array}{c}28 \\
(9.4)\end{array}$ & $\begin{array}{c}29 \\
(9.0)\end{array}$ & $\begin{array}{c}16 \\
(7.6)\end{array}$ & $\begin{array}{c}12 \\
(7.7)\end{array}$ & $\begin{array}{c}10 \\
(6.6)\end{array}$ & $\begin{array}{c}11 \\
(6.79)\end{array}$ & $\begin{array}{c}7 \\
(5.38)\end{array}$ & $\begin{array}{c}6 \\
(5.1)\end{array}$ & $\begin{array}{c}6 \\
(5.3)\end{array}$ & $\begin{array}{c}6 \\
(5.5)\end{array}$ & $\begin{array}{c}4 \\
(5.0)\end{array}$ & $\begin{array}{c}6 \\
(6.2)\end{array}$ & $\begin{array}{c}6 \\
(5.8)\end{array}$ & $\begin{array}{c}6 \\
(6.2)\end{array}$ \\
\hline $\begin{array}{l}\text { peritoneum } \\
\text { (peritonitis, } \\
\text { ascites) } \\
\text { [animals] (\%) }\end{array}$ & $\begin{array}{c}12 \\
(3.3)\end{array}$ & $\begin{array}{c}16 \\
(5.0)\end{array}$ & $\begin{array}{c}16 \\
(5.3)\end{array}$ & $\begin{array}{c}20 \\
(6.4)\end{array}$ & $\begin{array}{c}12 \\
(5.8)\end{array}$ & $\begin{array}{c}8 \\
(5.2)\end{array}$ & $\begin{array}{c}6 \\
(4.0)\end{array}$ & $\begin{array}{c}6 \\
(3.7)\end{array}$ & $\begin{array}{c}4 \\
(3.08)\end{array}$ & $\begin{array}{c}4 \\
(3.4)\end{array}$ & $\begin{array}{c}4 \\
(3.6)\end{array}$ & $\begin{array}{c}4 \\
(3.7)\end{array}$ & $\begin{array}{c}2 \\
(2.5)\end{array}$ & $\begin{array}{c}2 \\
(2.1)\end{array}$ & $\begin{array}{c}4 \\
(3.8)\end{array}$ & $\begin{array}{c}2 \\
(2.1)\end{array}$ \\
\hline $\begin{array}{l}\text { soft tissues } \\
\text { and bones } \\
\text { (injuries, } \\
\text { surgical } \\
\text { diseases) } \\
\text { [animals] }(\%)\end{array}$ & $\begin{array}{c}8 \\
(2.2)\end{array}$ & $\begin{array}{c}8 \\
(2.5)\end{array}$ & $\begin{array}{c}12 \\
(4.0)\end{array}$ & $\begin{array}{c}16 \\
(5.1)\end{array}$ & $\begin{array}{c}12 \\
(5.7)\end{array}$ & $\begin{array}{c}8 \\
(5.2)\end{array}$ & $\begin{array}{c}8 \\
(5.2)\end{array}$ & $\begin{array}{c}10 \\
(6.17)\end{array}$ & $\begin{array}{c}8 \\
(6.15)\end{array}$ & $\begin{array}{c}8 \\
(6.9)\end{array}$ & $\begin{array}{c}8 \\
(7.1)\end{array}$ & $\begin{array}{c}6 \\
(5.6)\end{array}$ & $\begin{array}{c}6 \\
(7.5)\end{array}$ & $\begin{array}{c}6 \\
(6.2)\end{array}$ & $\begin{array}{c}6 \\
(5.8)\end{array}$ & $\begin{array}{c}6 \\
(6.2)\end{array}$ \\
\hline $\begin{array}{l}\text { distal } \\
\text { extremities } \\
\text { [animals] }(\%)\end{array}$ & $\begin{array}{c}4 \\
(1.1)\end{array}$ & $\begin{array}{c}4 \\
(1.25)\end{array}$ & $\begin{array}{c}8 \\
(2.7)\end{array}$ & $\begin{array}{c}7 \\
(2.5)\end{array}$ & $\begin{array}{c}4 \\
(1.9)\end{array}$ & $\begin{array}{c}4 \\
(2.6)\end{array}$ & $\begin{array}{c}4 \\
(2.6)\end{array}$ & $\begin{array}{c}4 \\
(2.47)\end{array}$ & $\begin{array}{c}4 \\
(3.08)\end{array}$ & $\begin{array}{c}4 \\
(3.4)\end{array}$ & $\begin{array}{c}4 \\
(3.6)\end{array}$ & $\begin{array}{c}4 \\
(3.7)\end{array}$ & $\begin{array}{c}4 \\
(4.8)\end{array}$ & $\begin{array}{c}5 \\
(5.2)\end{array}$ & $\begin{array}{c}6 \\
(5.8)\end{array}$ & $\begin{array}{c}5 \\
(5.2)\end{array}$ \\
\hline $\begin{array}{l}\text { joints (without } \\
\text { distal } \\
\text { extremities) } \\
\text { [animals] (\%) }\end{array}$ & $\begin{array}{c}0 \\
(0)\end{array}$ & $\begin{array}{c}4 \\
(1.25)\end{array}$ & $\begin{array}{c}4 \\
(1.3)\end{array}$ & $\begin{array}{c}4 \\
(1.3)\end{array}$ & $\begin{array}{c}6 \\
(2.9)\end{array}$ & $\begin{array}{c}4 \\
(2.6)\end{array}$ & $\begin{array}{c}6 \\
(4.0)\end{array}$ & $\begin{array}{c}6 \\
(3.7)\end{array}$ & $\begin{array}{c}4 \\
(3.08)\end{array}$ & $\begin{array}{c}5 \\
(4.3)\end{array}$ & $\begin{array}{c}6 \\
(5.3)\end{array}$ & $\begin{array}{c}6 \\
(5.5)\end{array}$ & $\begin{array}{c}5 \\
(6.2)\end{array}$ & $\begin{array}{c}7 \\
(7.3)\end{array}$ & $\begin{array}{c}8 \\
(7.7)\end{array}$ & $\begin{array}{c}8 \\
(8.3)\end{array}$ \\
\hline $\begin{array}{l}\text { other systems } \\
\text { and organs } \\
\text { [animals] }(\%)\end{array}$ & $\begin{array}{c}8 \\
(2.2)\end{array}$ & $\begin{array}{c}12 \\
(3.75)\end{array}$ & $\begin{array}{c}8 \\
(2.7)\end{array}$ & $\begin{array}{c}7 \\
(2.5)\end{array}$ & $\begin{array}{c}4 \\
(1.9)\end{array}$ & $\begin{array}{c}3 \\
(1.9)\end{array}$ & $\begin{array}{c}3 \\
(2.0)\end{array}$ & $\begin{array}{c}3 \\
(1.85)\end{array}$ & $\begin{array}{c}4 \\
(3.08)\end{array}$ & $\begin{array}{c}5 \\
(4.3)\end{array}$ & $\begin{array}{c}5 \\
(4.5)\end{array}$ & $\begin{array}{c}6 \\
(5.5)\end{array}$ & $\begin{array}{c}4 \\
(5.0)\end{array}$ & $\begin{array}{c}6 \\
(6.2)\end{array}$ & $\begin{array}{c}6 \\
(5.8)\end{array}$ & $\begin{array}{c}6 \\
(6.2)\end{array}$ \\
\hline $\begin{array}{l}\text { Total } \\
\text { [animals] }\end{array}$ & 368 & 320 & 300 & 312 & 208 & 154 & 150 & 162 & 130 & 116 & 112 & 108 & 80 & 96 & 104 & 96 \\
\hline
\end{tabular}




\section{Conclusion}

The analysis of the results of studies on the structure of the causes of cattle retirement in two farms specializing in rearing and fattening of young cattle showed that the main options for retiring animals in fattening farms are mortality and necessary slaughter, which have a relatively complex nosological and thanatogenetic structure.

Moreover, the most widespread are pathological changes in the respiratory system, which in $51.9 \%$ of cases are background or concomitant diseases, and in $48.1 \%$ are the main cause of animal retirement. They are most widespread in young animals aged 4-6 months; while a peak of pathologies of the kidneys and urinary tract is also noted, due to which 7.6-9.4\% of animals are retired.

The second most important are gastrointestinal diseases, the most widespread of which occurs at the age of 3-4 months, during this period pathology of the liver and biliary tract is often observed, the relevance of which increases at the age of 7 to 18 months.

The role of cardiovascular pathology in the structure of the causes of retirement increases in young animals aged 8-11 months, while that of diseases of the joints and distal extremities rises at the final stage of their fattening.

Clinical and expert evaluation of the activity of veterinary specialists showed that one of the problems in diagnosing diseases in young cattle during the period of growing and fattening is an incomplete diagnosis due to the low detection rate of concomitant pathologies and complications, some of which are of decisive tanatogenetic significance.

\section{References}

1. A.S. Bolshakov, Technology of meat and meat products (Moscow, 2011)

2. Meat markets have reached the point. The availability of pork is almost $100 \%$, and the bird is expected to roll back Retrieved from: www.agroinvestor.ru/analytics/article/30893myasnye-rynki-doshli-do-tochki/

3. B.P. Holland, L.O. Burciaga-Robles, D.L. Van Overbeke, J.N. Shook et al., Effect of bovine respiratory disease during precondioning on subsequent feedlot performance, carcass characteriscs, and beef attributes J. Anim. Sci. 88(7), 2486-2499 (2010)

4. J.V. Gonzales-Marn, L. Elvira, M. C. Lopez, et al., Reducing an bioc use: Selecve metaphylaxis with florfenicol in commercial feedlots Livestock Sci. 141(2-3), 173-181 (2011)

5. L. Magrin, F. Gottardo, B. Contiero, M. Brscic, G. Cozzi, Time of occurrence and prevalence of severe lameness in fattening Charolais bulls: Impact of type of floor and space allowance within type of floor Livestock Sci. 221, 86-88 (2019)

6. C. Rumor, M. Brscic, B. Contiero, G. Cozzi, F. Gottardo, Assessment of finishing beef cattle mortality in a sustainable farming perspective Livestock Sci. 178, 313-316 (2015)

7. O.V. Zajrat'yants, L.V. Kakturskij, The formulation and comparison of clinical and pathologoanatomical diagnoses (Med. inform. agency, Moscow, 2011)

8. A.P. Kalashnikova, V.I. Fisinina, V.V. Shheglova, N.I. Klejmenova, Norms and diets feeding farm animals Reference manual 3rd ed. (Moscow, 2003)

9. SanPiN 2.1.4.1074-01. Drinking water. Hygienic requirements for water quality of centralized drinking water supply systems. Quality control: Sanitary rules and regulations (IIC Goskomsanehpidnadzora RF, Moscow, 2001)

10. A.V. Zharov, I.V. Ivanov, A.P. Stekolnikov, Autopsy and pathological diagnosis of animal diseases (Kolos, Moscow, 2000)

11. A.V. Zharov, Forensic veterinary medicine (Kolos, Moscow, 2001)

12. D.V. Bogomolov, I.N. Bogomolova, V.A. Putintsev, M.YA. Baranova et al., Forensic diagnosis of the cause of death and the establishment of tanatogenesis by morphological methods: method, recommendations (Russian Center for Forensic Medicine, Moscow, 2012)

13. M. Montes de Oca, M.V. Lopez Varela, A. Acuna et al., ALAT-2014 chronic obstructive pulmonary disease (COPD) clinical practice guidelines: questions and answers Arch Bronconeumol 51, 403-416 (2015)

14. T. Brack, A. Jubran, M.J. Tobin, Dyspnea and decreased variability of breathing in patients with restrictive lung disease Am. J. Respir. Crit. Care Med. 165(9), 1260-1264 (2002)

15. I.I. Dantsig, I.M. Skipskij, N.F. Levin, A.P. Melnikova, Nosocomial pneumonia in the thanatogenesis of patients with severe extrapulmonary pathology Pulmonology 6, 58-61 (2011)

16. Yu.I. Pigolkina, Forensic Medicine 3rd ed. (2012)

17. International Statistical Classification of Diseases and Related Health Problems 10th Revision (Geneva, 2016) 